\title{
KUALITAS PERAIRAN DI TELUK DORERI KABUPATEN MANOKWARI
}

\author{
Luky Sembel ${ }^{1}$, Emmanuel Manangkalangi ${ }^{2}$, Zulfikar Mardiyadi $^{3}$, \\ Abraham W. Manumpil ${ }^{1}$ \\ ${ }^{1}$ Jurusan IImu Kelautan, FPIK, Universitas Papua, Manokwari, \\ Papua Barat, Indonesia \\ ${ }^{2}$ Jurusan Perikanan, FPIK, Universitas Papua, Manokwari, Papua Barat, \\ Indonesia \\ ${ }^{3}$ Jurusan Manajemen Hutan, Fakultas Kehutanan, Universitas Papua, \\ Manokwari, Papua Barat, Indonesia \\ E-mail: lukysembel76@gmail.com
}

Received February 2019, Accepted April 2019

\begin{abstract}
ABSTRAK
Pasar Sanggeng, pasar Wosi, pelabuhan, PLTD (Pembangkit Listrik Tenaga Disel), perhotelan dan pemukiman penduduk yang terletak di pesisir Teluk Doreri Kota Manokwari, menjadi salah satu pusat aktivitas yang melayani kebutuhan masyarakat. Akibat adanya aktivitas yang tinggi tersebut menyebabkan pembungan sampah-sampah organik dan anorganik tidak terawasi atau terkontrol dengan baik. Kondisi ini berlangsung secara terus menerus setiap hari sehingga dapat menyebabkan terjadi degradasi kualitas perairan. Tujuan Penelitian yaitu untuk mengetahui status kualitas perairan di Teluk Doreri Kabupaten Manokwari. Penelitian dilakukan dari bulan Agustus tahun 2016 bertempat di Laboratorium Kelautan, IImu Kelautan Unipa dan Laboratorium Prolink IPB Bogor. Lokasi pengambilan sampel air di sekitar perairan Sawaibu, Wosi, Andai, Sowi dan Perairan Maruni. Data parameter yang diambil melalui pengukuran langsung dan tidak langsung. Pengukuran secara langsung meliputi parameter salinitas, $\mathrm{pH}$, suhu dan oksigen terlarut. Sedangkan pengukuran tidak langsung dengan cara mengambil sampel air. Pengambilan sampel air digunakan untuk penentuan parameter kekeruhan, nitrat, fosfat dan logam berat. Sampel air tersebut langsung dimasukan dalam botol polyetelin dan dikirim ke Prolink IPB Bogor untuk dianalisis. Pengukuran mengacu pada Standard Methods for the Examination of Water and Wastewater (APHA, 1998). Hasil penelitian dari lima lokasi di perairan Teluk Doreri berkisar antara 0,17 - 6,16 NTU untuk kekeruhan, 4,64 - 5,04 untuk $\mathrm{pH}, 5,1-6 \mathrm{mg} / \mathrm{L}$ untuk oksigen terlarut, 30 $33 \%$ untuk salinitas, $29,8-30,6{ }^{\circ} \mathrm{C}$ untuk suhu air, 0,1 -0,8 mg/L untuk nitrat dan fosfat berkisar $0,08-0,16 \mathrm{mg} / \mathrm{L}$. Hasil logam berat cadmium (Cd) menunjukan potensi toksik yang tinggi bagi biota perairan di Teluk Doreri. Parameter logam berat cadmium, nitrat dan fosfat sangat mengkuatirkan serta dapat menyebabkan gangguan terhadap lingkungan
\end{abstract}


khususnya bagi biota perairan. Parameter - parameter tersebut telah melampaui baku mutu yang ditetapkan kementerian lingkungan hidup no 51 tahun 2004.

Kata Kunci : Kualitas Air, Teluk Doreri, Manokwari

\section{ABSTRACT}

\section{WATER QUALITY IN THE DORERI BAY DISTRICT} MANOKWARI. Traditional markets (Pasar Sanggeng and Wosi), port, PLTD (Power Plant), hotels and residential areas are located in the cost of Doreri bay in Manokwari district. Activities in those areas create organic and inorganic wastes that have been used the Doreri bay as a water dump. The waste has been dumped since long time ago and continue up to nowadays. That cause water quality degradation of Doreri bay. The research objective was to determine the status of water quality in Doreri Bay, Manokwari Regency. The water quality study has been carried out in August 2016 in Marine laboratory of UNIPA and Prolink laboratory in IPB. Water samples collected from Sawaibu, Wosi, Andai, Sowi and Maruni beach. Data were divided base on the data collection which is directly and indirectly collected. Water salinity, $\mathrm{pH}$, temperature and dissolved oxygen are direct data collection. Turbidity, nitrate, phosphate and heavy metals are indirect data collection that has been analyzed in Prolink IPB. The water has been analyses by using Standard Method for Examination of Water and Wastewater (APHA, 1998). The results show that turbidity of five areas range from 0.17 to $6.16 \mathrm{NTU}, \mathrm{pH}$ range from 4.64 to 5.04 , dissolved oxygen between $5.1-6 \mathrm{mg} / \mathrm{L}$, water salinity range from $30-33 \%$, water temperature between $29,8-30.6{ }^{\circ} \mathrm{C}, 0.1-0.8 \mathrm{mg} / \mathrm{L}$ for nitrate and phosphate between $0.08-0.16 \mathrm{mg} / \mathrm{L}$. Heavy metal (cadmium) showed high potential toxic risk on the biota of Doreri bay. Cadmium, nitrate, and phosphate are a heavy metal that categorized as concerned pollutant to the Dorery bay. Those heavy metal have been exceeded the water quality standard base on Ministry of environment number 51-2004.

Keywords : Water Quality, Doreri Bay, Manokwari

\section{PENDAHULUAN}

Perairan Manokwari merupakan salah satu wilayah pesisir yang telah menjadi daerah pertumbuhan perekonomian dan pemukiman penduduk, diantaranya seperti perhotelan, pusat perbelanjaan serta pemukiman akibat adanya pengembangan Kota Manokwari. Namun demikian, di sisi lain berbagai kegiatan atau aktifitas manusia khususnya aktifitas pasar telah memberikan dampak yang negatif seperti penurunan kualitas air dan nilai estetika lingkungan yang diakibatkan oleh penumpukan sampah - sampah yang berasal di sekitar Pasar Sanggeng.

Pertambahan jumlah penduduk di Kabupaten Manokwari dari tahun ke tahun semakin meningkat. Tahun 2010 berjumlah 765.258 jiwa, tahun 
2011 berjumlah 785.979 jiwa, tahun 2012 berjumlah 806.995 jiwa, tahun 2013828.293 jiwa, tahun 2014 berjumlah 849.809 dan tahun 2015 berjumlah 871.510 jiwa. (BPS Prov.Papua Barat, 2016). Pertambahan penduduk akan diikuti pula dengan meningkatnya kawasan pemukiman penduduk serta semakin meningkatnya produk industri rumah tangga dan semakin berkembangnya kawasan industri dalam memicu terjadinya peningkatan pencemaran pada pesisir. Bahan organik dan anorganik yang masuk ke perairan dalam jumlah tertentu akan berguna bagi perairan tersebut, tetapi apabila jumlah yang masuk melebihi daya dukung perairan maka akan mengganggu fungsi perairan itu sendiri. Gangguan tersebut berupa pendangkalan dan penurunan mutu air, ketersediaan oksigen di perairan akan menjadi terbatas akibat penguraian bahan organik, baik yang terjadi di kolom air maupun di sedimen (Sanusi, 2006).

Pasar Sanggeng, Pasar Wosi, pelabuhan, PLTD (Pembangkit Listrik Tenaga Disel), perhotelan dan pemukiman penduduk yang terletak di pesisir Teluk Doreri Kota Manokwari, menjadi salah satu pusat aktivitas yang melayani kebutuhan masyarakat. Akibat adanya aktivitas yang tinggi tersebut menyebabkan pembungan sampah-sampah organik dan anorganik tidak terawasi atau terkontrol dengan baik. Sampah- sampah tersebut seperti sisa-sisa makanan, plastik, ceceran minyak, limbah perhotelan, limbah rumah sakit, limbah industri serta limbah rumah tangga. Kondisi ini berlangsung secara terus menerus setiap hari sehingga dapat menyebabkan potensi gangguan terhadap kualitas perairan. Indikator yang digunakan untuk mengetahui kondisi suatu perairan akibat limbah organik dan anorganik yang tinggi adalah dengan mengukur konsentrasinya yang dihubungkan dengan standar baku mutu menurut KLH 51 tahun 2004. Oleh sebab itu tujuan dari penelitian ini adalah mengetahui status kualitas perairan di Teluk Doreri Kabupaten Manokwari.

\section{MATERI DAN METODE}

Penelitian dilakukan bulan Agustus tahun 2016 bertempat di Laboratorium Kelautan, IImu Kelautan Unipa dan Laboratorium Prolink IPB Bogor. Lokasi pengambilan sampel air di sekitar Perairan Sawaibu, Wosi, Andai, Sowi dan Perairan Maruni. Data parameter yang diambil melalui pengukuran langsung dan tidak langsung. Pengukuran secara langsung meliputi parameter kecerahan, kekeruhan, salinitas, $\mathrm{pH}$, suhu dan oksigen terlarut. Sedangkan pengukuran tidak langsung dengan cara mengambil sampel air. Pengambilan sampel air digunakan untuk penentuan parameter nitrat, fosfat dan logam berat. Sampel air tersebut langsung dimasukan dalam botol polyetelin dan dikirim ke Prolink IPB Bogor untuk dianalisis. Pengukuran mengacu pada Standard Methods for the Examination of Water and Wastewater (APHA, 1998).

Hasil pengukuran karakteristik kualitas air yang diperoleh dibandingkan dengan standar baku mutu berdasarkan KepmenLH No. 51 Tahun 2004 tentang Penetapan Baku Mutu Air Laut. Pada prinsipnya 
metode ini membandingkan antara data kualitas dengan baku mutu yang disesuaikan dengan peruntukkannya guna menentukan status mutu air.

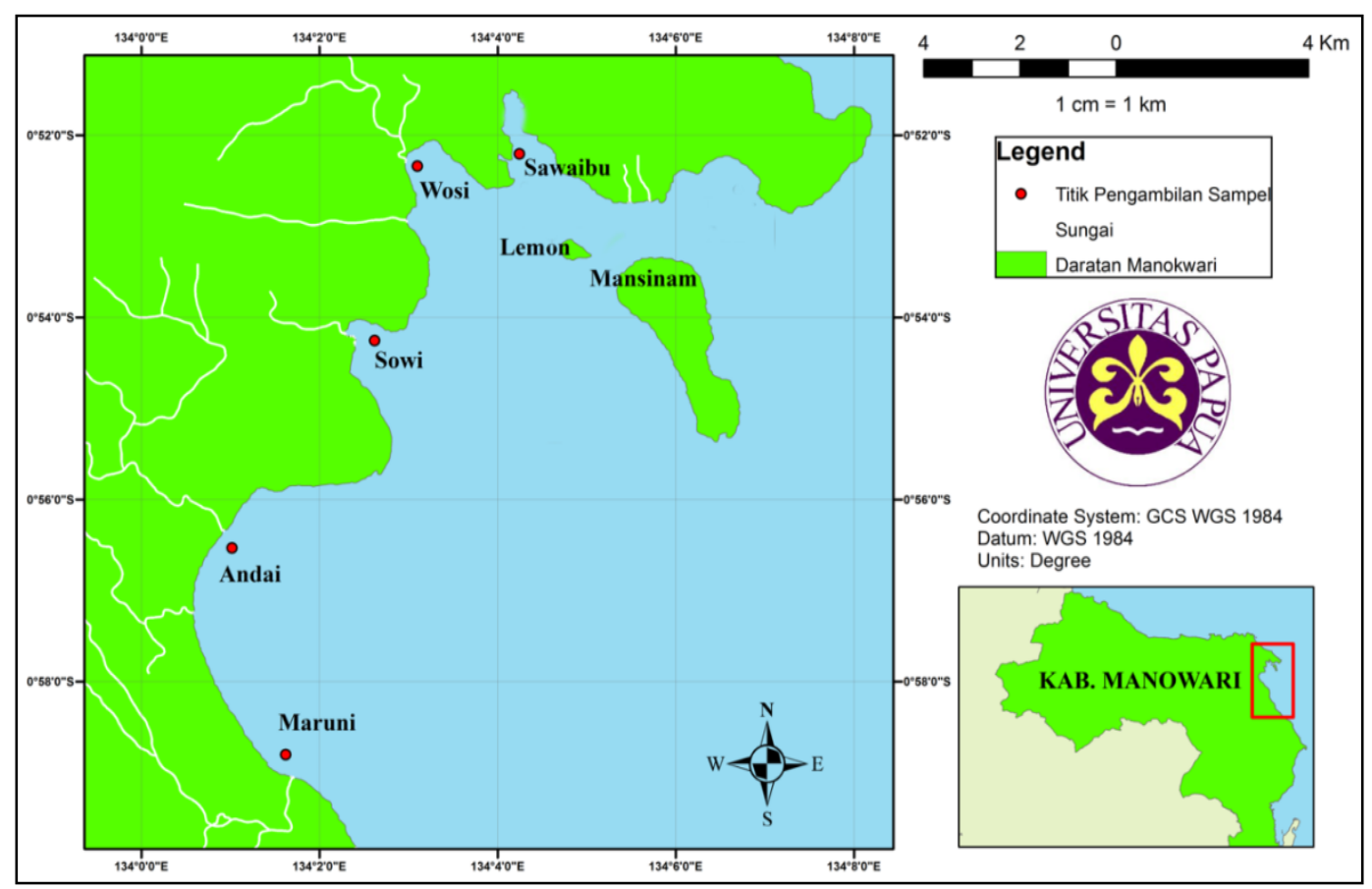

Gambar 1. Lokasi Penelitian Teluk Doreri Manokwari

\section{HASIL DAN PEMBAHASAN}

Teluk Doreri rentan terhadap pencemaran akibat aliran limbah dari daratan melalui sungai, saluran yang menuju ke teluk atau pembuangan langsung ke teluk. Secara fisik kimia kondisi perairan di teluk sangat dipengaruhi oleh siklus hidrologi, hidrodinamika, topografi, tata ruang dan intensitas pemanfaatan di wilayah teluk (Boyd, 1988). Komponen fisik kima berfungsi sebagai habitat dan media hidup komponen biotik ekosistem perairan. Komponen fisik kimia perairan teluk berperan sebagai media transportasi dan penyebaran limbah yang masuk ke teluk (Clark, 1986). Kajian ini mencoba mengulas dinamika kualitas perairan berdasarkan beberapa lokasi sehingga dapat diketahui status kualitas perairan Teluk Doreri. Hasil pengamatan suhu, salinitas, derajat keasaman $(\mathrm{pH})$ dan Oksigen Terlarut (DO) di permukaan perairan menunjukkan nilai yang bervariasi dan umumnya hanya sedikit berbeda dari beberapa hasil penelitian sebelumnya.

Tabel 1. Data Kualitas Air Teluk Doreri Kabupaten Manokwari $(n=27)$

\begin{tabular}{lcccc}
\hline Parameter & Min & Max & Rata-rata & Stdev \\
\hline Kekeruhan & 0,17 & 6,15 & 1,42 & 1,96 \\
Oksigen Terlarut (DO) & 5,1 & 6,3 & 5,63 & 0,41 \\
Suhu & 29,6 & 30,6 & 30 & 0,33
\end{tabular}




\begin{tabular}{lcccc}
\hline Parameter & Min & Max & Rata-rata & Stdev \\
\hline Salinitas & 30 & 33 & 31,6 & 1,32 \\
Ph & 4,64 & 5,04 & 4,92 & 0,13 \\
Fosfat & 0,08 & 0,26 & 0,15 & 0,06 \\
Nitrat & 0,1 & 0,8 & 0,6 & 0,23 \\
\hline
\end{tabular}

\section{Kekeruhan}

Padatan terlarut dan tersuspensi dalam kolom air mempengaruh tingkat kekeruhaan suatu perairan. Kekeruhan dapat mempengaruhi pernafasan ikan, proses fotosintesis dan produktivitas primer (Damar, 1996). Kekeruhan lapisan air disebabkan oleh kandungan bahan terlarut dan partikel tersuspensi seperti, jasad renik, lumpur, bahan organic, tanah liat, koloid dan benda terapung atau melayang yang tidak segera mengendap (Dunn et al,. 2007). Padatan tersuspensi berkolerasi positif dengan kekeruhan dan memiliki pola serta rasio yang sama (Hutabarat dan Evans, 1986)

\section{Kekeruhan}

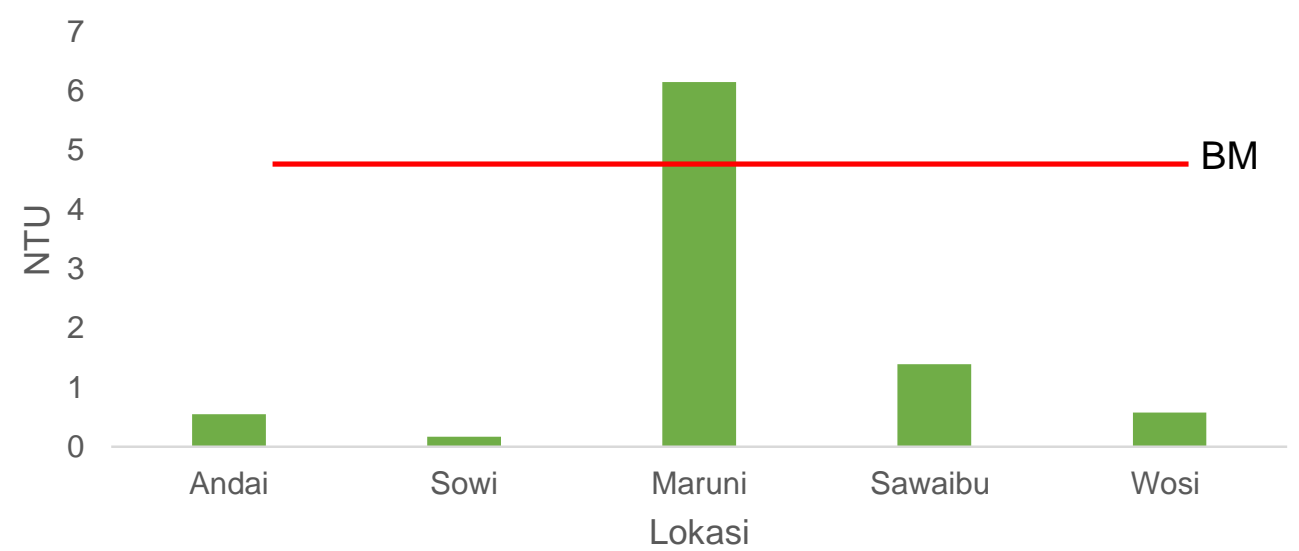

Keterangan : Baku Mutu (BM) KLH No. 51 Tahun 2004 (<5 NTU)

\section{Gambar 2. Sebaran Kekeruhaan}

Kekeruhan di perairan Teluk Doreri berkisar antara 0,17 - 6,15 NTU. Kekeruhan sangat dipengaruhi oleh curah hujan dan debit air yang masuk ke perairan. Hasil kekeruhan di lokasi Maruni agak tinggi akibat aktivitas yang terjadi dari pabrik semen, sebaliknya rendahnya kekeruhan di Sowi karena aktivitas masyarakat dan pengaruh dari sungai yang rendah.. Menururt Sembel dan Manan (2018), kekeruhan tinggi diakibatkan oleh berbagai pengaruh akitivitas yang berada di sekitar lokasi serta proses erosi pada daerah hulu sungai yang terbawa oleh aliran menunju laut.

Sebagaian besar kekeruhaan berada di bawah ambang batas yang masih dapat mendukung kehidupan berbagai organisme perairan, kecuali 
lokasi Maruni. Berdasarkan keputusan Menteri Lingkungan Hidup KEP No-51/MNLH///2004 sebagaian besar masih sesuai dengan standar baku mutu air untuk biota yaitu dibawah <5 NTU yang dapat menopang kehidupan biota perairan $(\mathrm{KLH}, 2004)$.

\section{Suhu}

Hasil pengukuran suhu permukaan air laut di sekitar perairan Teluk Doreri berkisar $29,6-30,6{ }^{\circ} \mathrm{C}$. Hasil pengamatan sebelumnya menunjukan suhu perairan Teluk Doreri berkisar $29,1-31,7^{\circ} \mathrm{C}$ saat surut dan $30,4-31,7^{\circ} \mathrm{C}$ saat pasang (Tururaja \& Mogea, 2010); $31,5-32,5^{\circ} \mathrm{C}$ (Alianto $d k k$. 2016) dan berkisar $29-30^{\circ} \mathrm{C}$ (Leatemia dkk., 2012). Kondisi suhu yang bervariasi disebabkan karena waktu pengambilan, kondisi cuaca serta intensitas cahaya (Nemerow, 1991). Berdasarkan sebaran suhu (gambar 3) di Teluk Doreri, suhu tertinggi berada di Andai dan terendah di Maruni. Perbedaan ini dapat disebabkan oleh adanya masukan air sungai ke laut. Masukan air sungai di Maruni lebih besar dibandingkan dengan Andai. Keadaan ini seperti yang dinyatakan oleh Effendi (2003) bahwa perubahan suhu air laut dapat terjadi akibat adanya masukan air sungai ke laut dan kodisi cuaca. Berdasarkan keputusan Kementerian Lingkungan Hidup No. 51 Tahun 2004 maka suhu untuk kehidupan biota laut masih baik untuk pertumbuhan.

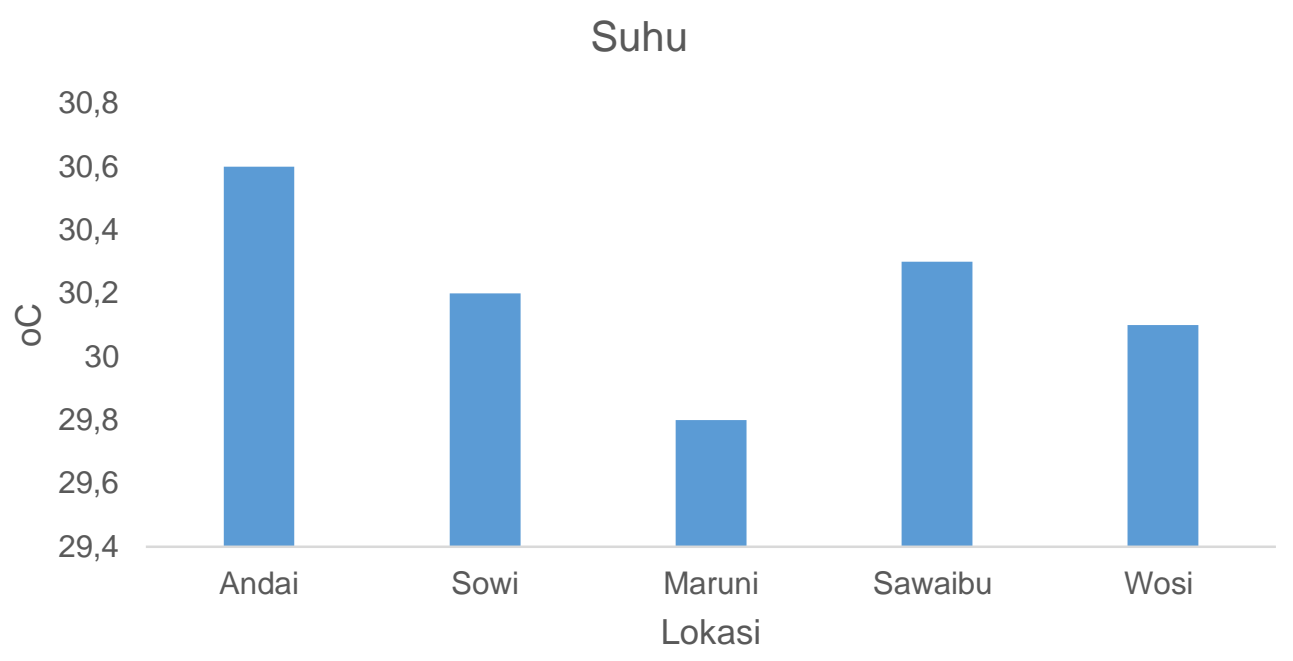

Gambar 3. Sebaran Suhu

\section{Salinitas}

Menurut Park et al (2005), salinitas air laut berfluktuasi tergantung pada musim, topografi, pasang surut dan jumlah masukan air tawar. Salinitas merupakan gambaran jumlah garam dalam suatu perairan. Sebaran salinitas dipengaruhi oleh berbagai faktor seperti pola sirkulasi air, penguapan, curah hujan dan aliran air sungai (Nontji, 1984). Hasil pengukuran salinitas di sekitar Teluk Doreri berkisar 30 - $33 \%$. Hasil 
pengamatan sebelumnya menunjukan salinitas perairan di Teluk Doreri berkisar 30 - $34 \%$ saat surut dan 30 - 33\% saat pasang (Tururaja \& Mogea, 2010); 31 - 34,5\% (Alianto dkk. 2016); dan berkisar 27 - $35 \%$ (Leatemia dkk. 2012). Rendahnya salinitas di Sawaibu karena adanya sungai dan bentuk lokasi yang semi tertutup sehingga sangat di pengaruhi oleh masukan air dari sungai (Gambar 4). Tingginya salinitas di Sowi karena sedikitnya masukan air sungai yang mengarah ke lokasi tersebut. Tinggi rendahnya salinitas sangat dipengaruhi oleh besarnya masukan air tawar dan tinggi rendahnya curah hujan (Quano, 1993).

\section{Salinitas}

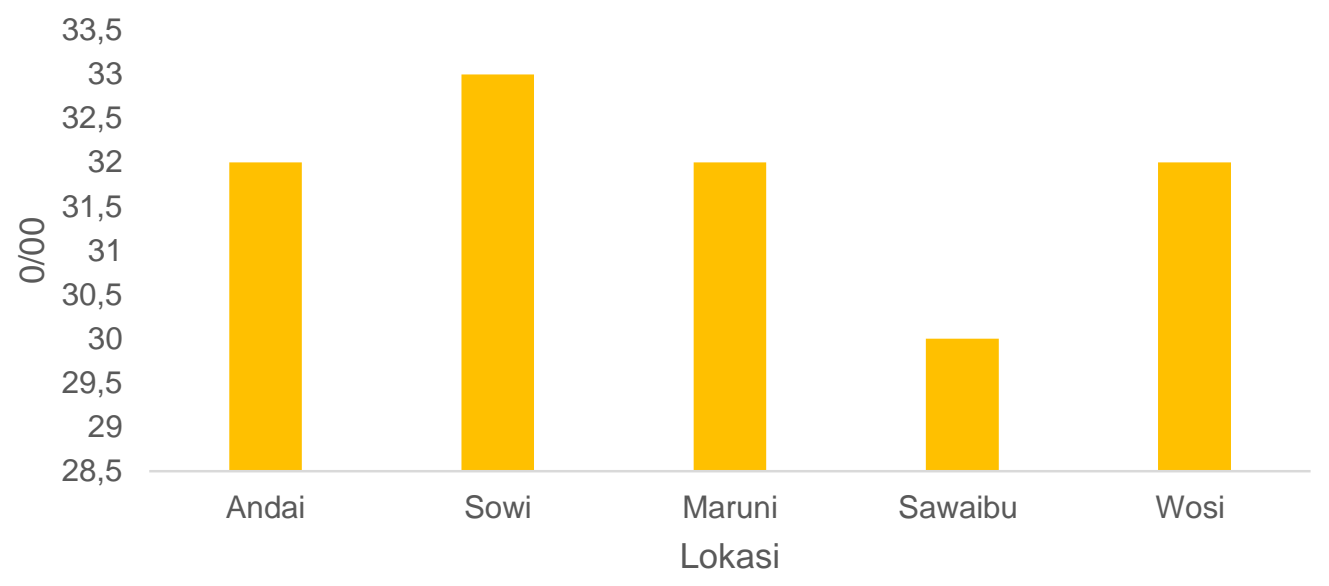

Gambar 4. Sebaran Salinitas

\section{Keasaman $(\mathrm{pH})$}

Derajat keasaman suatu perairan dipengaruhi oleh beberapa faktor antara lain oleh proses fotosintesis biologi dan adanya berbagai jenis kation dan anion di perairan tersebut (Nybakken, 1988). Tingkat keasaman yang diperoleh sekitar perairan Teluk Doreri menunjukkan nilai yang berfluktuasi yaitu 4,64 - 5,04. Hasil penelitian sebelumnya menunjukan sekitar $6,77-7,23$ saat surut dan $6,77-7,36$ saat pasang (Tururaja \& Mogea, 2010); 8 - 8,3 (Alianto dkk., 2016); dan 7 - 8,04 ( Leatemia $d k k ., 2017)$. Hasil penelitian menunjukan kondisi perairan yang relative mengarah keasam. Rendahnya $\mathrm{pH}$ dapat berasal dari tingginya fitoplankton khususnya Chrysophyta (Effendi, 2003). Kondiisi ini dapat menyebabkan mobilitas berbagai senyawa logam berat yang bersifat toksik semakin tinggi yang akan mengancam kelangsungan hidup organisme akuatik (Sembel, 2012). Merujuk pada baku mutu Kepmen LH No. 51 Tahun 2004 tentang baku mutu air laut untuk biota laut yaitu 7 8,5 maka kondisi pH perairan di sekitar Teluk Doreri relatif asam dan akan menggangu pertumbuhan biota yang berada di perairan tersebut. 


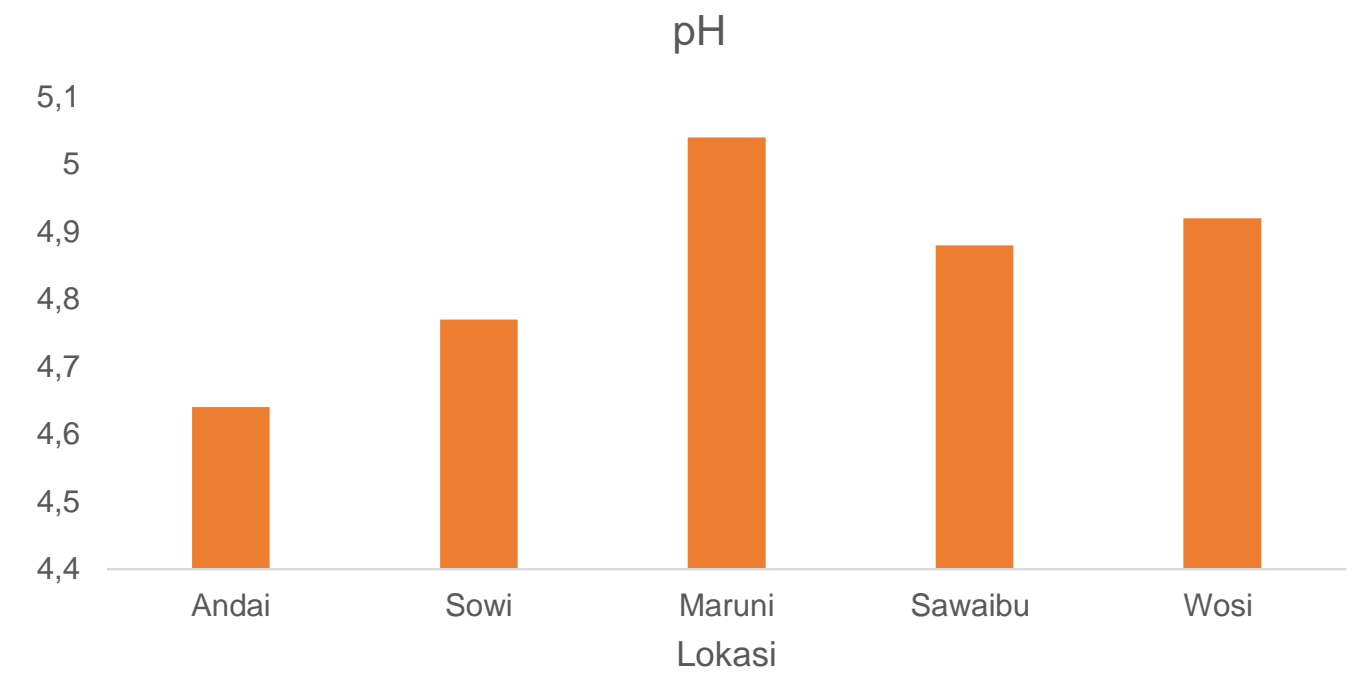

Keterangan : Baku Mutu (BM) KLH No. 51 Tahun 2004 (7 - 8,5)

Gambar 5. Sebaran $\mathrm{pH}$

\section{Fosfat}

Fosfor adalah unsur hara yang diperlukan oleh tumbuhan untuk berfotosintesis selain nitrogen. Dalam perairan, fosfor tidak ditemukan dalam bentuk bebas melainkan dalam bentuk senyawa anorganik yang terlarut (ortofosfat dan polifosfat) dan senyawa organik berupa partikulat (Jin et al., 2008). Fosfat merupakan bentuk fosfor yang dapat dimanfaatkan oleh tumbuhan dan merupakan unsur esensial bagi tumbuhan sehingga menjadi faktor pembatas yang akan mepengaruhi produktivitas perairan (Damar, 1996). Tingginya konsentrasi fosfat di Teluk Doreri disebabkan oleh buangan limbah rumah tangga dan aktivitas pasar oleh masyarakat. Fosfat di Teluk Doreri berkisar antara 0,08 - 0,26 mg/l. Selanjutnya penelitian sebelumnya oleh Alianto, dkk (2016) berkisar 0,017 - 0,038 mg/l Jika merujuk pada baku mutu Kepmen LH No. 51 Tahun 2004 tentang baku mutu air laut untuk biota laut yaitu 0,015 mg.l maka rata-rata konsentrasi fosfat Teluk Doreri telah melewati standar yang ditetapkan sehingga kondisi demikian dapat mengakibatkan potensi eutrofikasi dan dapat menganggu pertumbuhan dan perkembangan biota yang berada di perairan tersebut. Sumber fosfat berasal dari limbah pemukiman berupa detergen dan aktivitas pertanian berupa pemupukan. Tingginya konsentrasi fosfat di Sawaibu dapat disebabkan oleh tingginya aktivitas masyarakat dan padatnya pemukiman yang berada di sekitar lokasi, sebaliknya rendahnya konsentrasi di Andai karena rendahnya aktifitas dan kurangnya pemukiman di sekitar lokasi. Tingginya fosfat dapat menyebabkan potensi eutrofikasi yang dapat menyebabkan blooming hingga menyebabkan perairan menjadi beracun. 


\section{Distribusi Fosfat}

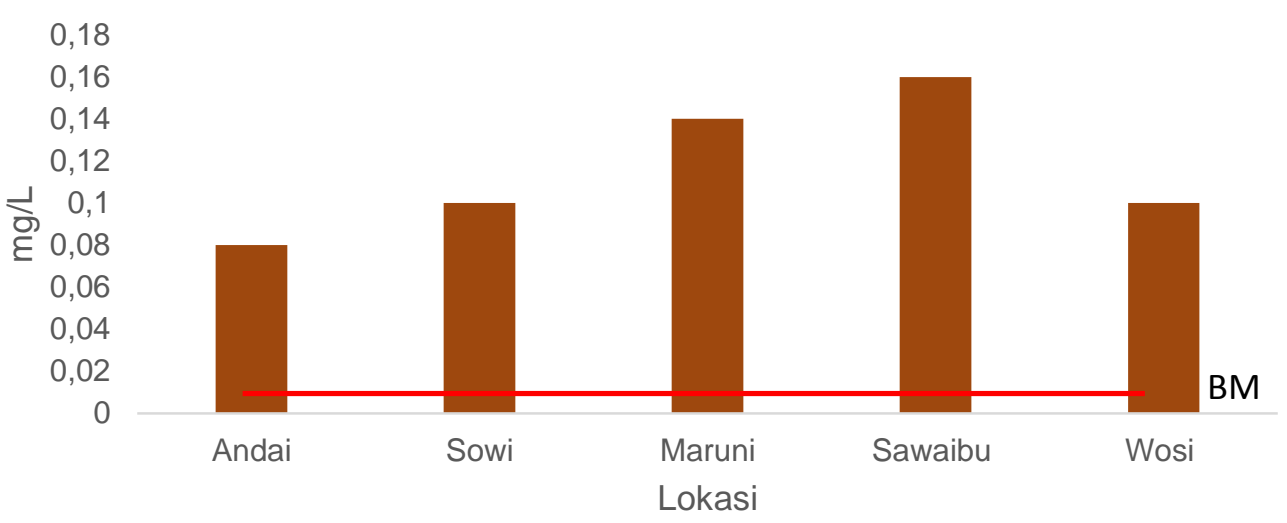

Keterangan : Baku Mutu(BM) KLH No. 51 Tahun 2004 (0,015 mg/l)

Gambar 6. Sebaran Fosfat

Nitrat

Salah satu senyawa nitrogen adalah Nitrat $\left(\mathrm{NO}_{3}\right)$ yang merupakan nutrien utama bagi pertumbuhan tanaman dan alga (Sanusi, 2006). Sumber utama unsur nitrat berasal dari daratan terutama dari limbah rumah tangga dan aktivitas pertanian yang masuk melalui aliran sungai Gambar 6 menunjukan rata-rata sebaran nitrat di Teluk Doreri berkisar 0,1 $-0,8 \mathrm{mg} / \mathrm{l}$. Penelitian sebelumnya yang telah dilakukan oleh Alianto, dkk (2016) berkisar 0,072 - 0,083 mg/L Tingginya konsentrasi nitrat di Maruni dan Sawaibu dapat disebabkan oleh aktivitas masyarakat di sekitar lokasi, sekitar lokasi Maruni terdapat perusahaan semen dan sekitar lokasi Sawaibu merupakan padatnya pemukiman dari penduduk. Sebaliknya rendahnya konsentrasi di Andai dapat disebabkan kurangnya aktivitas masyarakat dan kurangnya pemukiman

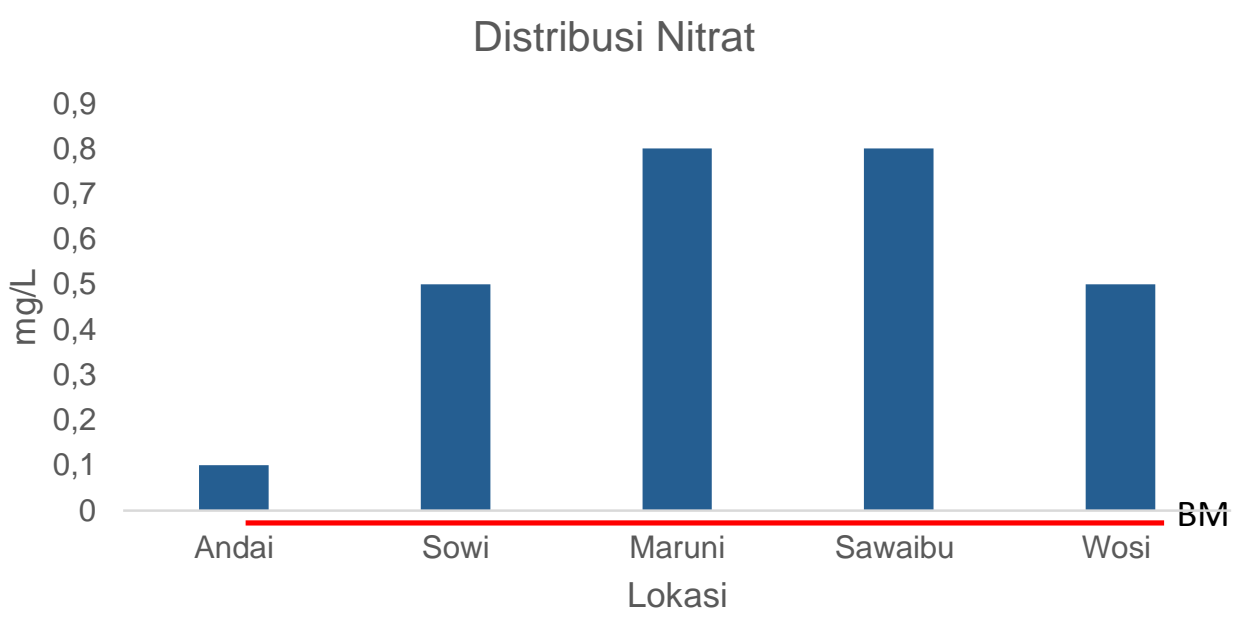

Keterangan : Baku Mutu (BM) KLH No. 51 Tahun 2004 (0,008 mg/L)

Gambar 7. Sebaran Nitrat 
Berdasarkan KepMen No.51/MENLH/2004, konsentrasi nitrat yang sesuai untuk kehidupan biota laut adalah $<0.008 \mathrm{mg} / \mathrm{L}$. Berdasarkan hasil penelitian yang diperoleh maka rata-rata konsentrasi nitrat Teluk Doreri telah melewati standar yang ditetapkan sehingga kondisi demikian dapat mengakibatkan potensi eutrofikasi dan dapat menganggu pertumbuhan dan perkembangan biota yang berada di perairan tersebut.

\section{Oksigen Terlarut (DO)}

Oksigen di perairan berasal dari difusi udara maupun hasil fotosintesis oleh organisme nabati, seperti fitoplankton dan tumbuhan air di zona eufotik (Kopalit, 2011). Karena sebagian besar organisme akuatik tidak dapat memanfaatkan oksigen bebas secara langsung, maka keberadaan oksigen terlarut dalam air sangat penting artinya bagi kehidupan biota di suatu perairan (Effendi, 2003) Sebaran kandungan oksigen terlarut di Teluk Doreri berkisar 5,1 - 6,3 mg/L. Hasil penelitian sebelumnya berkisar $1,21-5,32 \mathrm{mg} / \mathrm{L}$ saat surut dan $0,65-3,56 \mathrm{mg} / \mathrm{L}$ saat pasang (Tururaja \& Mogea, 2010); 0,65 - 6,01mg/L saat surut dan $3,71-5,67 \mathrm{mg} / \mathrm{L}$ saat Pasang (Sembel dan Manan, 2018); dan berkisar 2,20 - 7,83 mg/L (Leatemia, dkk. 2017). Jika dilihat berdasarkan hasil-hasil sebelumnya bahwa kisaran oksigen terlarut sangat berfluktuatif. Kondisi ini dapat disebabkan perbedaan waktu dan musim pengambilan. Fluktuasi oksigen terlarut juga dapat disebabkan oleh pengaruh suhu, salinitas dan curah hujan degradasi akan bahan organik rata-rata konsentrasi oksigen terlarut dari di setiap lokasi saat penelitian relatif baik (Gambar 8). Menurut Kementerian Lingkungan Hidup No. 51 Tahun 2004 tentang baku mutu yaitu $>5 \mathrm{mg} / \mathrm{L}$, maka kondisi Teluk Doreri relatif baik sehingga tidak menggangu kebutuhan oksigen dari biota perairan.

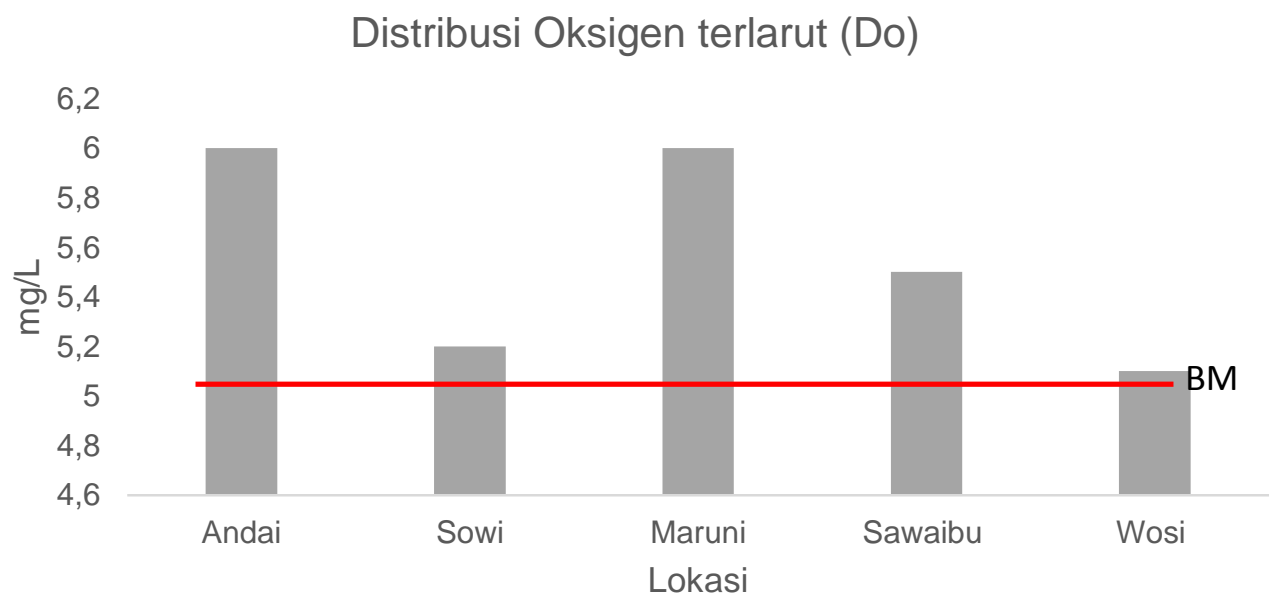

Keterangan : Baku Mutu KLH No. 51 Tahun 2004 (>5 mg/L)

Gambar 8. Sebaran (Oksigen Terlarut) 


\section{Logam Berat}

Sebaran logam berat $\mathrm{Cd}, \mathrm{Cu}, \mathrm{Pb}$ dan $\mathrm{Cr}^{6+}$ di Teluk Doreri menunjukan sebagian logam berat $\mathrm{Cu}, \mathrm{Pb}$ dan $\mathrm{Cr}^{6+}$ masih dibawah baku mutu kecuali Cd. Kondisi ini dapat di sebabkan oleh sumber pencemar dan aktivitas di sekitar lokasi serta sifat logam berat tersebut. Sifat dari logam berat $\mathrm{Cu}, \mathrm{Pb}$ dan $\mathrm{Cr}^{6+}$ cepat terhidrolisis sehingga cepat tercucikan, sedangkan sifat logam berat $\mathrm{Cd}$ agak sulit terhidrolisis (Kusuma, dkk. 2015). Tingginya logam berat $\mathrm{Cd}$ dapat bersumber dari kegiatan aktivitas yang berada di sekitar teluk doreri, seperti pelabuhan, pengecetan kapal, pembuangan air ballast, docking kapal, plastik, cat dan pipa air serta pengisian bahan bakar yang mampu memberi kontribusi logam berat ke perairan. Berdasarkan KepMen No.51/MENLH/2004, konsentrasi logam berat kadmium yang sesuai untuk kehidupan biota laut adalah $<0.001$ $\mathrm{mg} / \mathrm{L}$. Jika dihubungkan dengan hasil penelitian maka konsentrasi logam kadmium di Teluk Doreri telah melewati baku mutu. Kondisi ini dapat berbahaya bagi biota perairan lewat rantai makanan.

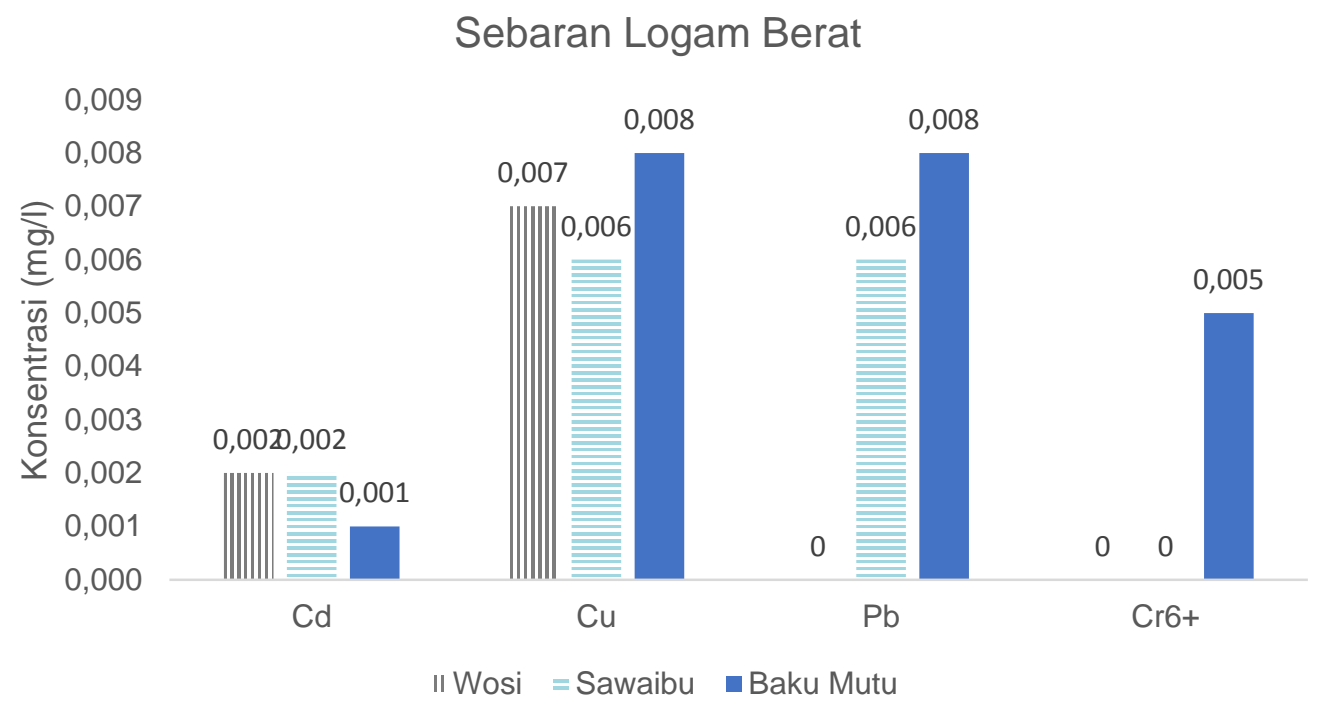

Gambar 9. Sebaran Logam Berat

\section{KESIMPULAN}

Status kualitas perairan di Teluk Doreri telah terganggu dengan tingginya nitrat, fosfat dan logam berat kadmium. Kondisi ini dapat menyebabkan potensi degradasi lingkungan dan resiko bencana bagi biota perairan. Logam berat kadmium dapat menyebabkan akumulasi di biota perairan dan dapat membahayakan manusia melalui rantai makanan. 


\section{DAFTAR PUSTAKA}

Alianto, Hendri, Suhaemi. 2016. Total nitrogen dan fosfat di perairan Teluk Doreri, Kabupaten Manokwari, Provinsi Papua Barat, Indonesia. Jurnal Depik. 5 (3) : 128-132.

APHA, 1998. Standard Methods for Exmanination of Water and Wastewater. New York.

Boyd, C.E. 1988. Water Quality in Warmwater Fish Ponds. Auburm University Agricultural Experimental Station. Alabama.

[BPS ] Papua Barat. 2016. Badan Pusat Statistik Papua Barat.

Clark RB. 1986. Marine Pollution. London : Clarendon Press.

Damar A. 1996. Pengaruh Penggunaan Lahan Terhadap Indeks Mutu Lingkungan Perairan dan Beban Limbah di Pesisir Indramayu [Tesis]. Bogor. Program Pascasarjana IPB Bogor.

Dunn RJK, Teasdale PR, Warnken J, Jordan MA, Arthur JM. 2007. Evaluation of the Insitu, Time-Integrated DGT Technique by Monitoring Changes in Heavy Metal Concentrations in Estuarine Waters. J Env Poll 148:213 -220.

Effendi H. 2003. Telah Kualitas Air (Bagi Pengelolaan Sumber Daya dan Lingkungan Perairan). Jogjakarta. Penerbit Kanisius.

Kopalit H. 2011. Struktur komunitas padang lamun di perairan Manokwari Papua Barat. Jurnal Perikanan dan Kelautan, 7(1): 9-18.

Hutabarat S, Evans SM.. 1986. Pengantar Oceanografi. Universitas Indonesia. Press. Jakarta.

Jin YX, Wang J, Zhang LuC, Duan Q. 2008. Effects of Modern and Ancient Human Activities on Mercury in the Environment in Xi'an Area, Shannxi Province, P.R. China. J Env Poll 153 :342 - 350.

[KLH] Kementerian Lingkungan Hidup No 51. 2004. Baku Mutu Air Laut. Deputi MENLH Bidang Kebijakan dan Kelembagaan Lingkungan Hidup.www.menlh.go.id/home.index.php.option=com.ontent=article =keputusan-menteri-negara-lingkungan-hidup-nomor-51-tahun2004-tentang-baku-mutu-air.[16 Juni 2010].

Kusuma Anma Hari, Tri Prartono, Agus Soleh Atmadipoera, Taslim Arifin.2015. Sebaran Logam Berat Terlarut Dan Terendapkan Di Perairan Teluk Jakarta. Jurnal Teknologi Perikanan dan Kelautan Vol. 6 No. 1 Mei 2015: 41-50. 
Leatemia SPO, Setyobudiandi I, Riani E. 2012. Komposisi dan kepadatan lamun di pesisir Manokwari, Provinsi Papua Barat. Jurnal Perikanan dan Kelautan, 8(1): 25-36.

Nemerow NL. 1991. Stream, Lake, Estuari, and Ocean Pollution. Van Nostrand Remhold. New York.

Nontji, A. 1984. Laut Nusantara. Jembatan Jakarta.

Nybakken JW. 1988. Biologi Laut: suatu pendekatan ekologis. Eidman HM, Koesoebiono, Bengen DG, Hutomo M, Sukardjo S (alih bahasa). Jakarta: PT. Gramedia. Terjemahan dari: Marine Biology: An Ecological Approach.

Park GS, Chung CS, Lee SH, Hong GH, Kim SH, Park SY, Yoon SJ, Lee SM. 2005. Ecotoxicological Evaluation of Sewage Sludge Using Bioluminescent Marine Bacteria and Rotifer. J Oce Sci 40 (2) : 91100.

Quano. 1993. Training Manual on Assessment of the Quantity and Type of Land Based Pollution Discharge Into The Marine and Coastal Enviroment. Bangkok. UNEP.

Sanusi HS. 2006. Kimia Laut (Proses Fisik Kimia dan Interaksinya dengan Lingkungan). Edisi Pertama. Penerbit Departemen Ilmu dan Teknologi Kelautan, Bogor. FPIK IPB.

Sembel L. 2012. Analisis Beban Pencemar dan Kapasitas Asimilasi di Estuari Sungai Belau Teluk Lampung. Maspari Journal 4 (2) 178183.

Sembel L, J.Manan. 2018 Kajian Kualitas Perairan pada Kondisi Pasang Surut di Teluk Sawaibu Kabupaten Manokwari. Jurnal Sumberdaya Akuatik Indopasifik. Vol II(1-14).

Tururaja T, R. Mogea. 2010. Bakteri Coliform di Perairan Teluk Doreri, Manokwari Aspek Pencemaran Laut dan Identifikasi Species. IImu Kelautan Undip. Maret 2010. vol. 15 (1) $47-52$. 